\title{
Lumen
}

Selected Proceedings from the Canadian Society for Eighteenth-Century Studies

\section{The Mystery of Aesthetic Response: Dryden and Johnson on Shakespeare}

\section{Nicholas Hudson}

Volume 30, 2011

URI : https://id.erudit.org/iderudit/1007713ar

DOI : https://doi.org/10.7202/1007713ar

Aller au sommaire du numéro

Éditeur(s)

Canadian Society for Eighteenth-Century Studies / Société canadienne d'étude du dix-huitième siècle

ISSN

1209-3696 (imprimé)

1927-8284 (numérique)

Découvrir la revue

Citer cet article

Hudson, N. (2011). The Mystery of Aesthetic Response: Dryden and Johnson on Shakespeare. Lumen, 30, 21-31. https://doi.org/10.7202/1007713ar

Copyright (c) Canadian Society for Eighteenth-Century Studies / Sociéte canadienne d'étude du dix-huitième siècle, 2011
Ce document est protégé par la loi sur le droit d'auteur. L'utilisation des services d'Érudit (y compris la reproduction) est assujettie à sa politique d'utilisation que vous pouvez consulter en ligne.

https://apropos.erudit.org/fr/usagers/politique-dutilisation/ 


\section{The Mystery of Aesthetic Response: Dryden and Johnson on Shakespeare}

The year 1678 marked an important and formative moment in the history of Shakespearian criticism. It was in the this year that John Dryden read a copy of Thomas Rymer's The Tragedies of the Last Age, which the author had sent him. Dryden was so absorbed by this book that he drew up a detailed list of responses on the end-leaves. Rymer's book, though inelegantly written and, in many respects, little more than a sustained rant against the tragicomedies of the early seventeenth century, struck a chord with Dryden, and it evidently influenced a change in the direction of his own dramatic theory and practice. Dryden was seeking just such a change. Mocked in satires such as The Rehearsal by Lord Buckingham and his circle, Dryden abandoned his beloved project of highheroic rhymed tragedy after Aureng-Zebe in 1675. He turned instead to Shakespeare, writing All for Love, his updated version of Antony and Cleopatra, in 1677, and then a new Troilus Cressida in 1679. To the printed versions of each of these plays, he added prefaces responding explicitly to Rymer. These short essays dwelt on what, in the preface to Troilus and Cressida, he called, in prescient style, "The Grounds of Criticism in Tragedy," for he sought to isolate the principles that made some tragedies more effective than others.

Samuel Johnson famously called Dryden "the father of English criticism,"1 seeing himself as the heir to Dryden's pioneering exploration of drama and other literary forms. As I will argue, what Dryden and Johnson had particularly in common was their insistence that the

1 Johnson, "Life of Dryden," in Lives of the Poets, ed. Roger Lonsdale, 4 vols. (Oxford: Clarendon Press, 2006), 2:118. 
pleasure we experience in viewing or reading drama - what later terminology called aesthetic response - offered the primary guide for assessing artistic quality and the greatness of Shakespeare. Rymer's Tragedies of the Last Age, which Johnson also knew well, persuaded Dryden of the deficiency of tragicomedy, at least as written by its most famous practitioners, Francis Beaumont and John Fletcher. But Dryden also believed that Rymer's reasons for rejecting tragicomedy were fundamentally incorrect. Rymer was a rule-bound critic who insisted on the classical unities and the absolute distinction between comedy and tragedy. Guided by these rules, Rymer would later undertake a prolonged assault on Shakespeare in A Short View of Tragedy (1693), a predictable attack, for Shakespeare had also committed the sin of mixing tragedy and comedy, the high and the low, in many of his plays. Dryden's objection to Rymer was essentially that Shakespeare's tragedies, despite breaking the rules, elicited a pleasurable and admiring response. New critical principles, principles concerning the nature and source of this response, were needed to explain this mysterious disjunction between the traditional rules of drama and Shakespeare's actual appeal. Following in Dryden's footsteps, Johnson and many of his eighteenth-century contemporaries would attribute this abiding appeal to what they called "nature" or "general nature." We need to consider, however, whether this principle of "nature" really solved the mystery of aesthetic response, or rather disguised continued uncertainty about the "grounds" of literary criticism.

Dryden's movement towards Shakespeare in the late 1670s is all the more striking because Shakespeare, while widely esteemed, had not yet achieved the pre-eminent stature he attained in the Age of Johnson. During the Restoration, his status was equaled, and even exceeded, by Beaumont and Fletcher. As Dryden observed in An Essay of Dramatic Criticism (1668), the plays of Beaumont and Fletcher "are now the most pleasant and frequent entertainments of the Stage; two of theirs being acted through the year for one of Shakespeare's or Johnsons." ${ }^{2}$ Year after year, Restoration audiences flocked to see these authors' most popular tragicomedies, Philaster, The Maid's Tragedy, and A King and No King. As this last play, first performed in 1611, was discussed in detail by both Rymer and Dryden, we might briefly consider it as an example of Beaumont and Fletcher's tragicomic theatre. The central character

2 John Dryden, An Essay of Dramatick Poesie, in The Works of John Dryden, 20 vols., gen. ed. H.T. Swedenberg and others (Berkeley and Los Angeles: University of California Press, 1956-2002), 17:57. 
of $A$ King and No King is Abraces, king of Iberia, who throughout the play swings between high-heroic vaunting and farcical vulgarity. He is indeed a great warrior, and his threats of destruction and revenge recall the vaunting of Achilles. Yet he also struggles absurdly with his guilty desire for his sister, Panthea. Incest is an old theme in tragedy, of course, but Beaumont and Fletcher make this taboo seem coarse and depraved, as if satirizing the tragic form itself. Burning with illicit desire, for example, Abraces pretends not to see his sister when she is standing right in front of him, much to the bewilderment of Panthea and the surrounding court. He eventually demeans himself by asking the clownish Captain Bessus to divulge his incestuous secret to Panthea. Bessus, a groveling low-life, quickly agrees, adding that if Abraces desires his mother, he could arrange that assignation as well. Horrified, the king himself recognizes that he is very like this comic buffoon, an affinity that had led modern scholarship to dwell on the playwrights' apparent undermining of royal dignity and the social hierarchy. The play's portrait of a degraded and comic king - a king yet no king - may well reflect dissatisfaction with James I's slovenly court and the real king's promotion of low-born male favorites to positions of prestige. King Abraces's repeated association with the yokel Bessus, his swings between heroism and farce, adumbrate a real disruption of social categories in Jacobean society, a confusion of high and low that tragicomedy projected onto the stage.

It was precisely this confusion between tragedy and comedy that enraged Rymer in the 1670s. While Rymer was himself low-born, the son of a Presbyterian radical hanged for treason in 1664, he worried deeply about the erosion of social roles in his own time. These anxieties about the decay of the social hierarchy were not unfounded. For all the pomp and circumstance of Charles II's reign, the decadence of his court exceeded all that Beaumont and Fletcher had witnessed in the court of "the merry monarch's" grandfather, James I. This was age of Nell Gwynn, the low-born actress who belonged to the procession of mistresses who paraded through the King's bed-chamber and who often wielded more power than the Queen. The theatre, much enjoyed by the King, displayed the upper-gentry as immoral and lawless, mirroring real-life gallants like Lord Rochester, whose circle hell-raked in taverns and in the streets with legal impunity, throwing every Puritan code to the winds. Himself a Puritan, Rymer reached back like Milton to an austere classical code to restore a moral and social discipline flouted, in his view, by the mode for tragicomedies. He insisted that tragedy should present only edifyingly noble exemplars. Kings should be regal, indeed heroic. "Though it is not necessary that all Heroes should be kings," he protested, "yet undoubtedly all crown'd heads by Poetic 
right are Heroes. ${ }^{\prime 3}$ It was not likely that Rymer would have shared the popular enthusiasm for A King and No King. So far from being a "hero," he fumed, we find Arbaces "drolling and quibbling with Bessus and his Buffoons." Indeed, "Captain Bessus is all modesty to him," ${ }^{5}$ for Bessus is at least innocent of desiring his own sister or flying into profane and tawdry rants. Most interesting about Rymer's tirade was his assumption that tragicomedy defied ancient standards that had always been obeyed until the reigns of Elizabeth and James I. In fact, Rymer was creating a strict division between tragedy and comedy, high and low forms, that had rarely existed in English or even foreign drama. Not only Beaumont and Fletcher, but also Shakespeare, Jonson, Middleton, Decker and Massinger routinely violated Aristotelian rules without any sense that they were revolutionizing the theatre. The model of Rymer's tragic ideal was in fact French. A translator of French works, Rymer was importing the rigid generic categories of Racine, Corneille, and the critic Réné Rapin, the servants of a Catholic and absolutist regime that, paradoxically, persecuted Protestants like Rymer himself.

Dryden was also from a Puritan background. Yet he had long wished to distinguish between the conventions of recent French theatre and what, in the Essay of Dramatic Poesy, he defended as the English theatre's characteristic mixture of comedy and tragedy: "A continued gravity keeps the spirit too much bent...A Scene of mirth mix'ed with Tragedy has the same effect upon us which our musick has betwixt Acts, which we find a relief to us from the best Plots and language of the Stage." ${ }^{6}$ In his prefatory essay to Troilus and Cressida, "The Grounds of Criticism in Tragedy," he conceded to Rymer that tragedy "ought to be great, and to consist of great Persons, to distinguish it from Comedy; where the Action is trivial, and the persons of inferior rank." ${ }^{7}$ But the greatness of tragedy or non-comic theatre did not, evidently, depend on making its noble characters into heroes or pristine exemplars. Shakespeare's Prince Hal, for example, retained his nobility despite his friendship with the unheroic Falstaff and his gang. Somehow, Hal remained noble despite his participation in comic low-life. And, in this respect, the future Henry V was unlike Abraces in A King

3 Thomas Rymer, The Tragedies of the Last Age ( $2^{\text {nd }}$ ed., London, 1692), p. 61.

4 Rymer, Tragedies of the Last Age, p. 64.

5 Rymer, Tragedies of the Last Age, p. 61.

6 See Dryden, Works, 17:46.

7 Dryden, Works, 13:231. 
and No King, a play Dryden credited solely to John Fletcher. Dryden confessed that Abraces moved his pity, one of the main ingredients of tragic response, a perplexing reaction since $A$ King and No King seems decidedly unsentimental. Yet Dryden also agreed that the Iberian king had too much in common with the clownish Bessus. Abraces was "a strange mixture of a man," ${ }^{8}$ a pitiful character who inspired sympathy for his human weakness, but who lacked the dignity always retained by the tragic heroes of Shakespeare. Dryden was asking the following question: how could this be? His mission in "The Grounds of Criticism in Tragedy" was to explain why the audience's reactions to mixed characters in Shakespeare were so different from its reactions to the tragicomic creations of Fletcher. Dryden's answer focused on questions of the hero's inner motivations. He set up a schema of inward personality, distinguishing unclearly between "manners," "characters," and "passions." "Manners" referred to "inclinations," which differ from person to person to produce "characters," who are in turn spurred to action by common "passions" like anger, hatred, love and jealousy. ${ }^{9}$ It was the correct mixture of these motivations in a character that directed audience response and made Shakespeare's tragic heroes more noble than those of Fletcher, despite Shakespeare's similar neglect of neo-classical rules.

The plausibility of this analysis is less impressive than Dryden's aim. He was working hard to articulate some new standard for evaluating both the success of a tragedy and the inward nobility of tragic characters. His analysis is foundational because he sought to isolate the causes of literary response rather than relying on abstracted critical laws. As Dryden was a playwright as well as a critic, he set out to put his theories into practice on the stage. By his own admission, his version of Shakespeare's Anthony in All for Love was intended to recreate that Shakespearian alchemy, a flawed hero who remained inherently noble and moving in appropriately tragic ways. ${ }^{10}$ Anthony's flaw is his overweening love for Cleopatra, for it struck Dryden that the capacity for epic love, a love that would consider the world well lost, was the ennobling flaw of a man who could just as well conquer that world. But it is not certain that Dryden distilled Shakespeare's tragic elixir. In many respects, All for Love seems connected with the burgeoning sentimen-

8 Dryden, Works, 13:240.

9 See Dryden, Works, 13:234-48.

10 See Dryden, Works, 13:10-11. 
talism of late 1670 's tragedy, a lachrymose trend that would continue into the eighteenth-century tragedies of Rowe and Addison. ${ }^{11}$ Anthony's amorous potency ironically unmans him, a paradox underlined by his vulnerability to the persuasions of Cleopatra's eunuch Alexas. We might feel sorry that Anthony can only weep limply in the face of Caesar's virile and unromantic militarism, but he seems what that age called "effeminate" rather than heroic.

Thomas Rymer, at least, remained unconvinced by Dryden's defense of Shakespeare. In A Short View of Tragedy, he accused Shakespeare, a man of common origins, of writing for "Carpenters, Cobblers, and illiterate Fellows;" Iago talked "the Language of the Exchange, or the Ensuring-Office;" noble Brutus seemed the "son of the Shambles, or some natural offspring of the Butchery." ${ }^{\prime 2}$ Rymer's lofty francophile pureté, this drive to sanitize social and generic distinctions, continued to influence criticism and dramatic practice into the early eighteenth century. In 1712, John Dennis accused Shakespeare of "great Absurdity" in making the nobleman Menenius in Coriolanus into an "arrant Buffoon." Dennis thought that the dramatization of "the Rabble" in both Coriolanus and Julius Caesar undermined the "Dignity" of these tragedies. ${ }^{13}$ Even David Garrick, later admired for making Shakespeare's tragic heroes so "natural," faced early criticism that, as his rival actor Samuel Foote complained, he played the raving King Lear like a "mad Taylor." ${ }^{\prime 14}$ Early eighteenth-century criticism, that is, continued to be influenced by an idealized vision of the social hierarchy that demanded perfect nobility in kings, lords and ladies, and that rejected the intrusion of comic elements into tragedy as coarse and vulgar. ${ }^{15}$ The authority of this traditional social vision is evidenced in tragedies such as Congreve's The Mourning Bride, Rowe's Tamerlane, and Addison's Cato,

11 On this sentimental trend, see Eric Rothstein, Restoration Tragedy: Form and the Process of Change (Madison, Milwaukee, and London: University of Wisconsin Press, 967), pp. 90-110.

12 Thomas Rymer, A Short View of Tragedy, (London, 1693), pp. 111, 5, 151.

13 John Dennis, An Essay on the Genius and Writings of Shakespeare (London, 1712), p. 4.

14 Samuel Foote, A Treatise on the Passions, So Far as They Regard the Stage (London, 1747), p. 21.

15 On social class-based criticisms of Shakespeare in the early eighteenth century, see Nicholas Hudson, "Shakespeare's Ghost: Johnson, Shakespeare, Garrick, and Constructing the Middle Class," in Aaron Santesso and Eric Rasmussen, eds., Comparative Excellence: New Essays on Shakespeare and Johnson (New York: AMS, 2007), pp. 47-69. 
in which these playwrights struggled to maintain the nobility of their heroes while also obeying the Aristotelian rule that tragedy inspires "fear and pity" through the hero's self-inflicted downfall.

Particularly in the wake of the Glorious Revolution and the Hanoverian Succession, however, this traditional social order was under severe pressure. In 1688, the English removed the direct heir to the throne; in 1714, the Whigs, with their strong connections with great merchants and financiers in the City of London, began their long reign in political power. The largely aristocratic theatre audiences of the Restoration were replaced by a broadened audience open to the enriched middle-ranks. This audience was far more willing, like John Dryden, to consult its private sense of pleasure rather than rules drawn from the absolutist regime across the Channel. In being an instrument of this pleasure, Shakespeare became, as Pope observed in his 1725 edition of Shakespeare, "not so much the Imitator, as the Instrument of Nature. ${ }^{\prime 16}$ Rymer's neo-classical rules lost their authority. In one of the first studies entirely devoted to the appreciation of Shakespeare, Shakespeare Illustrated (1753-4), Charlotte Lennox roundly assailed Rymer's class-bound and rule-bound assessment of Shakespearian tragedy. ${ }^{17}$ Of course Iago could be morally degraded, she wrote, since evil was as prevalent among high ranking soldiers as among everyone else. Similarly, Garrick's acting, once reviled for its defiance of class boundaries, became admired as "natural." The following lines from Charles Churchill's The Rosciad (1761) echoed widespread praise for Garrick's naturalism, a quality he achieved particularly through his interpretation of Shakespearian tragic heroes:

But when from Nature's pure and genuine source,

These strokes of Acting flow with gen'rous force;

When in the features all the soul's portray'd,

And passions, such as GARRICK's, are display'd

To me they seem from quickest feelings caught:

Each start is Nature; and each pause a Thought. ${ }^{18}$

In these lines, I would highlight two features. First, Garrick seemed to Churchill, as to many others, to display the interiority of Shakespeare's

16 In Brian Vickers, Shakespeare: The Critical Heritage, 6 vols. (London, Henley and Boston: Routledge and Kegan Paul, 1974-81), 2:404.

17 See Vickers, Shakespeare, 4:118.

18 In Vickers, Shakespeare, 4:438. 
characters. Garrick's mobile features displayed the "soul"; his very pauses shadowed forth a "Thought." Dryden, it seems, was correct in associating the naturalness of Shakespeare with an individual identification with the psychology of the playwright's creations. Second, Churchill's praise of Garrick's performance of Shakespeare derived from his theatrical experience of Garrick's "gen'rous force." The rules of Aristotle, Rapin or Rymer meant little to Churchill because he had experienced theatrical pleasure in Garrick's Drury Lane, against which the rigid boundaries of neo-classicism melted into irrelevance.

Dryden, as we have seen, had also relied on his affective experience as a reader and viewer of Shakespeare: Abraces failed for him as a noble character whereas Prince Hal had not, reactions that he concluded must have some critical "grounds." The torch tossed from "the father of English criticism" to Johnson was meant to light the way towards a form of aesthetic explanation that no longer depended on abstract rules about what an art-form should be. In his preface to Shakespeare, Johnson corroborated Dryden's challenge to neo-classical rules. "Shakespeare's plays," he wrote, "are not in the rigorous and critical sense either tragedies or comedies." ${ }^{19}$ Rather, they succeeded because they conveyed "pleasure," a response that, like his contemporaries, Johnson equated with "nature." "Nothing can please many, and please long," he famously observed, "but just representations of general nature." ${ }^{20} \mathrm{He}$ dismissed as "the petty cavils of petty minds" the neo-classical complaints of Rymer, Dennis and Voltaire that Shakespeare failed to keep up the appropriate dignity of his kings and high-ranking characters:

His adherence to general nature has exposed him to the censure of criticks, who form their judgments upon narrower principles. Dennis and Rymer think his Romans not sufficiently Roman; and Voltaire censures his kings as not completely royal. Dennis is offended, that Menenius, a senator of Rome, should play the buffoon; and Voltaire perhaps thinks decency violated when the Danish usurper is represented as a drunkard...[Shakespeare's] story requires Romans and kings, but he thinks only on men. He knew that Rome, like every other city, had men of all dispositions; and wanting a buffoon, he went into the senatehouse for that which the senate-house would certainly have afforded him. ${ }^{21}$

19 The Yale Edition of the Works of Samuel Johnson, gen. eds. A.T. Hazen, J.H. Middendorf, and others, 16 vols. (New Haven and London: Yale University Press, 1958- ), 7:66.

20 Works, 7:61.

21 Works, 7:67-8. 
As a literary critic, as in other areas of his thought, Johnson was a selfconscious empiricist, a thinker who relied on the belief that experience provided the exclusive source of all that we call knowledge. Unlike Dryden, he wrote in the light of John Locke's exposition of empiricism, which Johnson fully absorbed. ${ }^{22}$ It was partly this epistemological selfawareness that accounts for his revisions to Dryden's critical practice. First, Johnson made little effort to pin down the "grounds" of aesthetic judgment. Neither the preface to Shakespeare, nor his other critical works, attempted to refine on Dryden's schema of "manners," "characters," and "passions," or to provide a set of principles for assessing why audiences have historically liked Hamlet more than A King and no King. It was enough, for Johnson, that Shakespeare, unlike other writers, had given consistent pleasure to audiences for over more than a century. Second, Johnson concerned himself with the problem of proving objectivity in aesthetic response. Dryden, along with later commentators, relied more or less uncritically on their own individual responses, which they tended to generalize into the reactions of all audiences at every time. As a self-conscious empiricist, Johnson believed that an individual response to a reading or live performance proved very little, for this experience absorbed a congeries of extraneous ideas derived from an individual's daily life at a particular time. Fashion, prejudice, personalities all impinge on the experience of artistic pleasure. These experiences could be identified as extraneous only by the passage of time. Only time, by neutralizing momentary and ephemeral sources of pleasure, could be trusted to separate what was superficial and false in the judgment of art from what was essential and permanent, what Johnson called "general nature."

Johnson's empiricist methodology, and particularly his equation between consistent aesthetic pleasure and "general nature," will of course strike most scholars in our post-modern environment as deeply naïve. It is perhaps not widely noticed how anti-empiricist post-modernist ideas have become, a tendency that has sharply divided departments of literature from departments in the sciences and social sciences. For Jacques Derrida, for example, empiricism is a "non-philosophy," for it allegedly fails to account for its own ontology and the endless play

22 On Johnson's empiricism, see Robert Voitle, Samuel Johnson the Moralist (Cambridge, MA: Harvard University Press, 1961), chap. 1, pp. 1-21; Paul Kent Alkon, Samuel Johnson and Moral Discipline (Evanston, IL: Northwestern University Press, 1967, chap. 3, pp. 85-108. Specficially on empiricism in Johnson's aesthetic thought, see William Edinger, Samuel Johnson and Poetic Style (Chicago and London: University of Chgicago press, 1977), chap. 3, pp. 78-101. 
of language and figuration. ${ }^{23}$ In turn, Marxists have historically vilified empiricism as a buttress to the structures of ideological power, ${ }^{24}$ an argument that has led scholars from Foucault to the New Historicists to place both "nature" and the "human" under deeply-scored erasure. Such developments have led to our tendency to underrate the seminal and even revolutionary nature of a critical tradition that took its rise in Dryden and flourished in the age of Johnson, a time that also transformed Shakespeare into the "Bard of Avon," the hero of Garrick's 1769 Stratford Jubilee. This revolution consisted of releasing Shakespeare, and by extension a great deal of creative writing, from the abstract idea that art should accord with rules claimed to be eternal, though in fact of dubious provenance and longevity. In questioning Rymer's rule-bound neo-classicism, and reverting instead to an analysis of "The Grounds of Criticism in Tragedy," Dryden implicitly referred the reader or viewer back to what he or she personally thought, individually and affectively.

To this degree he lay the grounds not only of literary criticism in the eighteenth century, but of the whole tradition of criticism leading from the Age of Johnson to our time. Over the past few decades there has, perhaps, been some reversion back to methodologies analogous to Rymer's appeal to extraneous rules and principles in the assessment of Shakespeare or any literary text. It would seem very often that what counts as "theory" actually means the replacement of Aristotle as unquestionable authority with a pantheon of more recent avatars - Foucault, Spivak, Greenblatt, Habermas or, to a diminished degree, Marx - whose doctrines and practices are taken as a priori guides to literary analysis. On the other hand, Dryden's or Johnson's claim that literary analysis is in the first instance an individual response free from constraining rules and that the object of analysis should be the elucidation of the grounds of our judgments, remains, if in a disguised form, the rationale of most literary criticism, even in our post-modern era. In interpreting a Shakespearean text, in justifying or analyzing our responses in relation to the text, we remain the heirs of "the father of

23 See "Violence and Metaphysics: An Essay on the Thought of Emmanuel Levinas," in Writing and Difference, trans. Alan Bass (London, Melbourne and Henley: Routledge and Kegan Paul, 1978), pp. 151-2. For fuller discussion of Derrida's ambivalent critique of empiricism, see Nicholas Hudson, "Philosophy/Non-Philosophy and Derrida's (Non) Relations with Eighteenth-Century Empiricism," in Alexander Dick and Christina Lupton (London: Pickering and Chatto, 2008), pp. 11-30.

24 See, eg., Terry Eagleton, Criticism and Ideology: A Study in Marxist Political Theory (London, NLB, 1976), pp. 16-17. 
English criticism" and of his more direct descendents in the eighteenth century.

NICHOLAS HUDSON

University of British Columbia 